7. Reprod. Fert. (1970) 22, 375-378

\title{
EFFECT OF ADRENALINE ON SUCCINIC DEHYDROGENASE ACTIVITY AND MORPHOLOGY OF THE MID-PIECE OF MICE SPERMATOZOA
}

\author{
V. B. AYYAGARI AND D. P. MUKHERJEE \\ Division of Animal Genetics, Indian Veterinary Research Institute, Izatnagar, India
}

(Received 2nd February 1970)

\begin{abstract}
Summary. The mid-piece of fully matured mouse spermatozoa showed differential dehydrogenase activity. With the decreased activity, the breadth and area of the mid-piece decreased. Injection of $0.06 \mathrm{mg}$ of adrenaline/male decreased the percentage of spermatozoa with high dehydrogenase activity.
\end{abstract}

Mukherjee \& Ayyagari (1969) reported that administration of adrenaline reduced the area and breadth of the mid-piece of fully matured mice spermatozoa. This reduction was thought to be due to a reduction in the blood supply (and hence oxygen supply) to the spermatozoa. As succinic dehydrogenase is involved in oxidative and anaerobic metabolic processes of spermatozoa, the object of the present experiment was to determine (i) if the succinic dehydrogenase activity was reduced by adrenaline injection and (ii) if the activity was correlated in any way with the area and breadth of the mid-piece of mouse spermatozoa.

Forty, colony-bred, adult, male albino mice were allotted at random to control and experimental groups, each consisting of twenty mice. The origin of the mouse colony and the amount $(0.06 \mathrm{mg}$ in $0.06 \mathrm{ml}$ saline) and mode of administration of adrenaline tartrate to each mouse of the experimental group were the same as reported previously (Mukherjee \& Ayyagari, 1969). Each mouse of the control group received a total of $0.06 \mathrm{ml}$ saline in six equal doses over 2 days. As before, the mice of the two groups were maintained in a room where the air temperature varied between 25 and $27^{\circ} \mathrm{C}$.

Two hours after the last injection, mice of the two groups were killed by dislocation of the neck. From each mouse, the two vasa deferentia were dissected out and cleaned externally. Their contents were squeezed out with the aid of a pair of forceps into a drop of normal saline and thoroughly mixed. The drop was then transferred into an agglutination tube, maintained at $37^{\circ} \mathrm{C}$, containing a drop of $0.1 \mathrm{M}$-sodium succinate and a drop of incubating medium. The composition of the incubating medium was $10 \mathrm{mg}$ of Nitro B.T. (B.D.H.) in $10 \mathrm{ml}$ of $0.1 \mathrm{M}$-phosphate buffer, $\mathrm{pH} \mathrm{7.5}$. After incubation for $1 \mathrm{hr}$, four smears were made from each of the control and experimental males. The smears were dried in air, fixed in formol saline and stained with eosin $Y$ according to the method described by Hrudka (1965). 
The 160 slides from the forty mice, eighty for each group, were coded and examined unmounted under a microscope with an oil-immersion objective and blue filter. Fifty spermatozoa per slide were selected at random and the dehydrogenase activity of their mid-pieces was graded as follows:

Classification (Plate 1)

$++++=$ Mid-piece exhibiting intensely stained, large-sized and densely packed granules (Fig. 1, 1)

$+++=$ Mid-piece exhibiting moderately sized granules with intense staining (Fig. 1, 2)

$++=$ Mid-piece exhibiting intenselystained, loosely-packed granules in one region and packed granules in another region (Fig. 2, 3)

$+=$ Mid-piece exhibiting small and loosely-packed granules (Fig. 1, 4)

$-=$ Mid-piece without stained granules (Figs. 1 and 2, 5)

To study the mensuration characteristics of the mid-piece with different succinic dehydrogenase activity, two out of the four coded slides from each of the ten males of the control and experimental groups were used. A total of forty slides, twenty from the control and twenty from the experimental group were examined. Under a projection microscope, at a linear magnification of $\times 6 \cdot 169$, spermatozoa, two for each of the five classes, were selected at random from each slide. The mid-pieces of the selected spermatozoa were drawn on separate sheets of paper. There were ten drawings from each slide. The drawings were

TABLE 1

GROUP MEANS, ANGULAR PERGENTAGE AND ANALYSIS OF VARIANCE OF THE MID-PIEGE CHARACTERISTICS

\begin{tabular}{|c|c|c|c|c|c|c|}
\hline \multirow[b]{2}{*}{ Group means } & \multirow[b]{2}{*}{ d.f. } & \multicolumn{5}{|c|}{ Succinic dehydrogenase activity } \\
\hline & & ++++ & +++ & ++ & + & - \\
\hline $\begin{array}{l}\text { Control mean } \\
\text { Experimental mean }\end{array}$ & & $\begin{array}{l}29 \cdot 11 \\
22 \cdot 63\end{array}$ & $\begin{array}{l}32 \cdot 16 \\
26 \cdot 75\end{array}$ & $\begin{array}{l}1.96 \\
1.82\end{array}$ & $\begin{array}{l}30 \cdot 73 \\
30 \cdot 73\end{array}$ & $\begin{array}{l}20 \cdot 10 \\
33 \cdot 05\end{array}$ \\
\hline $\begin{array}{l}\text { Analysis } \\
\text { Groups } \\
\text { Mice within group } \\
\text { Slides within mice }\end{array}$ & $\begin{array}{r}1 \\
38 \\
120\end{array}$ & $\begin{array}{c}1680 \cdot 13 \\
638 \cdot 80^{* *} \\
54 \cdot 19\end{array}$ & $\begin{array}{c}1171 \cdot 86^{*} \\
191 \cdot 36^{* *} \\
40 \cdot 93\end{array}$ & $\begin{array}{l}\quad 0.75 \\
25 \cdot 85^{* *} \\
13.67\end{array}$ & $\begin{array}{c}0.001 \\
497 \cdot 75^{* *} \\
105 \cdot 83\end{array}$ & $\begin{array}{c}6713.41^{* *} \\
699.56^{* *} \\
55.94\end{array}$ \\
\hline
\end{tabular}

coded to veil their classification before measurements were made on them for length, breadth and projected area. The projection microscope used and the method of measurement have already been described (Mukherjee \& Ayyagari, 1969). The average mid-piece length, breadth and area were determined for each class of spermatozoa present on a slide.

The percentages of spermatozoa with different classes of mid-piece were transformed into angles and statistically analysed. The group means and details of analysis of variance are given in Table 1 . The mean square between mice within a group was used to test the mean square between groups. The results of the analysis showed that administration of adrenaline decreased the proportion of spermatozoa with ' +++ ', and increased the proportion of spermatozoa with 


\section{PLATE 1}

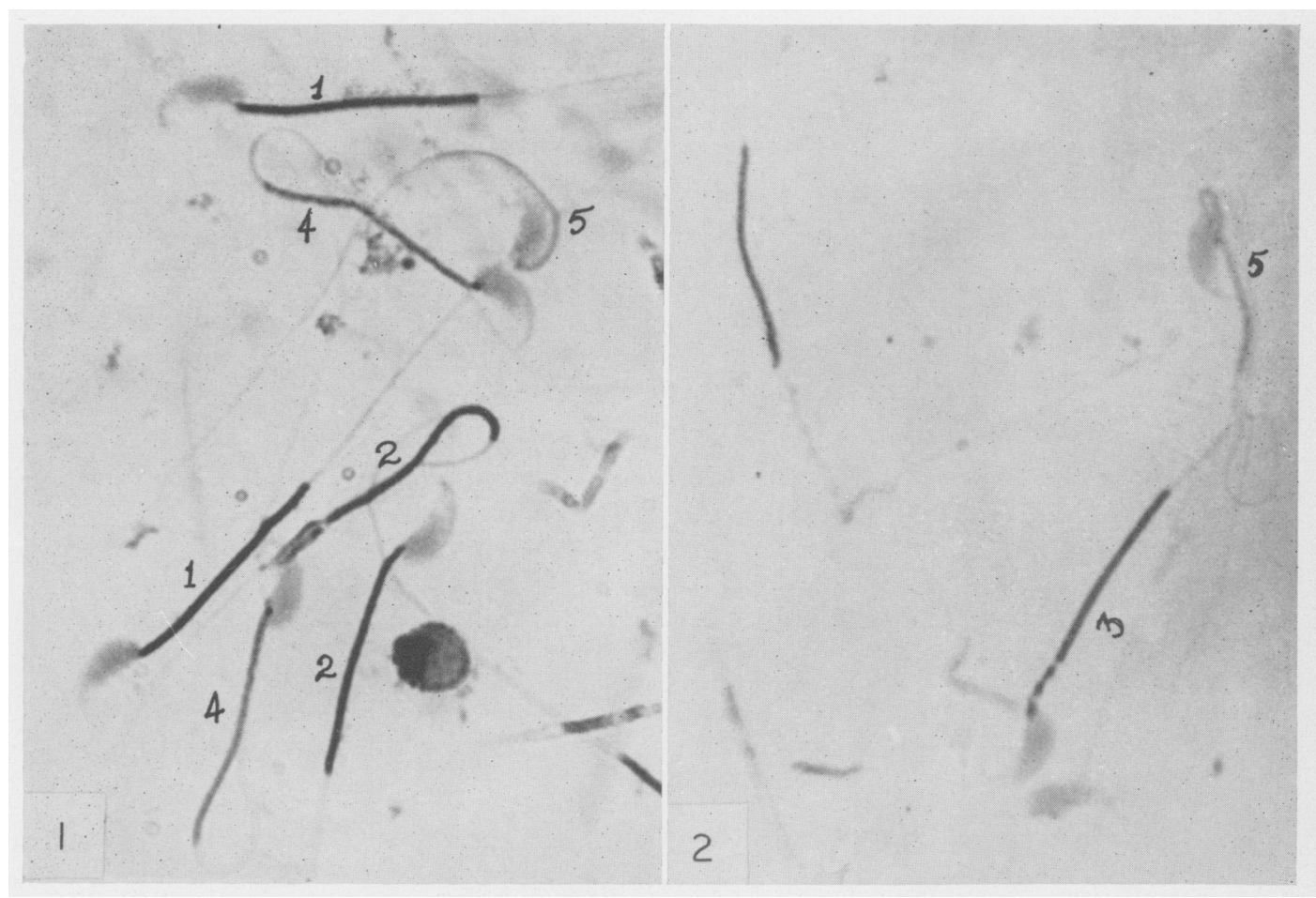

FIGs. 1 and 2. Mid-pieces of mice spermatozoa with different dehydrogenase activity. 
PLATE 2

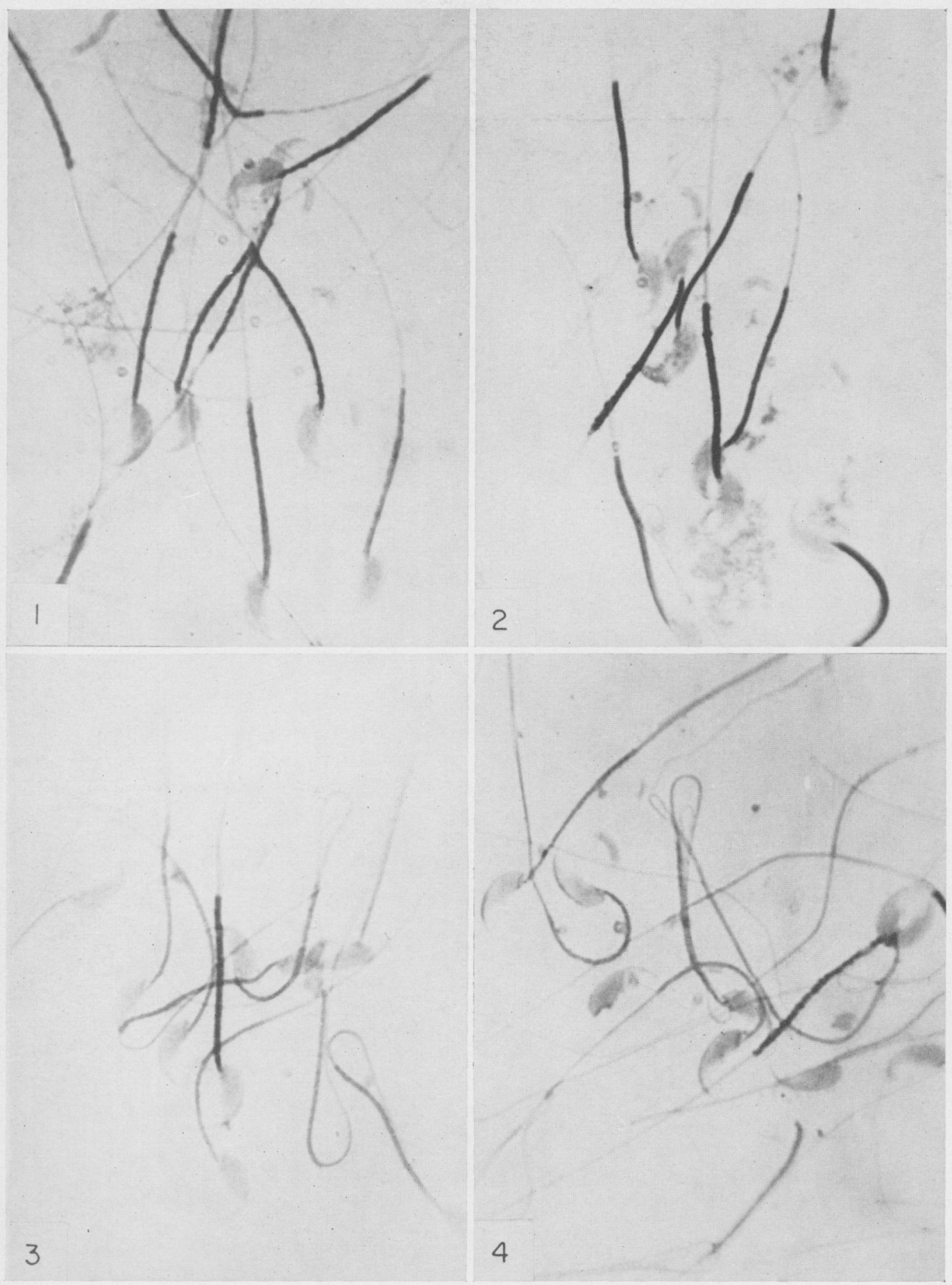

FIGs. 1 to 4. Mid-pieces of mice spermatozoa showing dehydrogenase activity. Figs. 1 and 2 of the control group and Figs. 3 and 4 of the experimental group.

(Facing p. 377) 
'-', succinic dehydrogenase activity. To test this result, four slides from four males of the control and experimental groups were selected at random and photographed. The micrographs confirmed the results obtained (Plate 2).

Group means of the mensuration characteristics of the mid-piece of different classifications are given in Table 2 and the details of an analysis of variance of the characteristics are given in Table 3 . The mean squares due to interactions were tested against the error mean squares and were found to be statistically non-significant. They were, therefore, pooled for mid-piece area and breadth, and the pooled error mean square (with 156 d.f.) was used to test the mean squares between classes. To test the mean square between mice within a group, interaction mean squares between classes and mice within groups were used. As

TABLE 2

GROUP MEANS OF THE MENSURATION GHARACTERISTICS OF THE MID-PIEGE

\begin{tabular}{|c|c|c|c|c|c|c|}
\hline \multirow[b]{2}{*}{ Characteristics } & \multirow[b]{2}{*}{ Group means } & \multicolumn{5}{|c|}{ Succinic dehydrogenase activity } \\
\hline & & $+++t$ & $++t$ & ++ & + & - \\
\hline Mid-piece area $\left(\mu^{2}\right)$ & $\begin{array}{l}\text { Control } \\
\text { Experimental }\end{array}$ & $\begin{array}{l}18 \cdot 04 \\
17 \cdot 65\end{array}$ & $\begin{array}{l}15 \cdot 74 \\
16 \cdot 10\end{array}$ & $\begin{array}{l}15 \cdot 41 \\
15 \cdot 77\end{array}$ & $\begin{array}{l}14 \cdot 30 \\
14 \cdot 72\end{array}$ & $\begin{array}{l}12 \cdot 17 \\
12 \cdot 31\end{array}$ \\
\hline Mid-piece length $(\mu)$ & $\begin{array}{l}\text { Control } \\
\text { Experimental }\end{array}$ & $\begin{array}{l}21 \cdot 89 \\
21 \cdot 96\end{array}$ & $\begin{array}{l}21 \cdot 78 \\
21 \cdot 79\end{array}$ & $\begin{array}{l}20 \cdot 98 \\
21 \cdot 13\end{array}$ & $\begin{array}{l}21 \cdot 59 \\
21 \cdot 13\end{array}$ & $\begin{array}{l}21 \cdot 16 \\
21 \cdot 66\end{array}$ \\
\hline Mid-piece breadth $(\mu)$ & $\begin{array}{l}\text { Control } \\
\text { Experimental }\end{array}$ & $\begin{array}{l}0.824 \\
0.804\end{array}$ & $\begin{array}{l}0.712 \\
0.739\end{array}$ & $\begin{array}{l}0.721 \\
0.718\end{array}$ & $\begin{array}{l}0.662 \\
0.677\end{array}$ & $\begin{array}{l}0.547 \\
0.567\end{array}$ \\
\hline
\end{tabular}

TABLE 3

ANALYSIS OF VARIANCE OF THE MENSURATION CHARAGTERISTIGS OF THE MID-PIECE

\begin{tabular}{|c|c|c|c|c|}
\hline Analysis & d.f. & $\begin{array}{c}\text { Mid-piece area } \\
\left(\mu^{2}\right)\end{array}$ & $\begin{array}{l}\text { Mid-piece length } \\
(\mu)\end{array}$ & $\begin{array}{c}\text { Mid-piece breadth } \\
(\mu)\end{array}$ \\
\hline $\begin{array}{l}\text { Glasses } \\
\text { Groups } \\
\text { Mice within group } \\
\text { Slides within mice } \\
\text { Glasses } \times \text { Group } \\
\text { Glasses } \times \text { Mice within groups } \\
\text { Error } \\
\text { Pooled error }\end{array}$ & $\begin{array}{r}4 \\
1 \\
18 \\
20 \\
4 \\
72 \\
80 \\
156\end{array}$ & $\begin{array}{l}168 \cdot 441 * * \\
1.724 \\
3.844 * * \\
0.476 \\
1.432 \\
1.079 \\
0.819 \\
0.955\end{array}$ & $\begin{array}{l}0 \cdot 166 \\
0 \cdot 147 \\
1 \cdot 313^{*} \\
0 \cdot 316 \\
0 \cdot 555 \\
0 \cdot 397 \\
0 \cdot 625 \\
-\end{array}$ & $\begin{array}{l}0.3437 * * \\
0.0014 \\
0.0048^{* *} \\
0.0012 \\
0.0031 \\
0.0020 \\
0.0014 \\
0.0017\end{array}$ \\
\hline
\end{tabular}

the error mean square for mid-piece length was more than the interaction mean square, it was used to test the mean square between classes and between mice within a group. For all the three characteristics of the mid-piece, mean square between groups was tested against the mean square between mice within a group.

As the means of the mid-piece area and breadth varied between classes, the differences between means were tested according to the method described by Snedecor (1957). It was found that for both mid-piece area and breadth, the differences were significant, except between classes showing ' +++ ' and ' ++ ' activity.

From the results of the present experiment, it was concluded that administra- 
tion of adrenaline to mice reduced the percentage of spermatozoa with high dehydrogenase activity. The results also indicated that, with the decrease in the dehydrogenase activity, the area and breadth of the mid-piece also decreased. As the mid-piece area and breadth of spermatozoa with the same dehydrogenase activity did not vary between the control and the experimental groups, it was also concluded that reduction in the area and breadth of the mid-piece of mice spermatozoa as reported previously by Mukherjee \& Ayyagari (1969) was due to a reduction in the number of spermatozoa with high dehydrogenase activity in the semen samples obtained after adrenaline injection. Beatty \& Sharma (1960) and Beatty (1962) reported strain differences in the length and breadth of the mid-piece of mouse spermatozoa. It appears from the present result that the succinic dehydrogenase activity of the mid-piece may also vary between different strains of mice.

\section{REFERENGES}

Beatty, R. A. (1962) Recent research on fertilization and the phenotype of mammalian gametes. Symp. genet. biol. ital. 9, 328.

Beatty, R. A. \& Sharma, K. N. (1960) Genetics of gametes. III. Strain differences in spermatozoa from eight inbred strains of mice. Proc. R. Soc. Edinb. B, 68, 25.

HRUDKA, F. (1965) Gytochemical demonstration of catabolic activity in spermatozoa by the formazan test. F. Reprod. Fert. 10, 15.

Mukherjee, D. P. \& AyYagari, V. B. (1969) Effect of atropine and adrenaline on the morphology of mice spermatozoa. F. Reprod. Fert. 20, 143.

SNedecor, G. W. (1957) Statistical methods, p. 251. The Iowa State College Press, Ames, Iowa. 